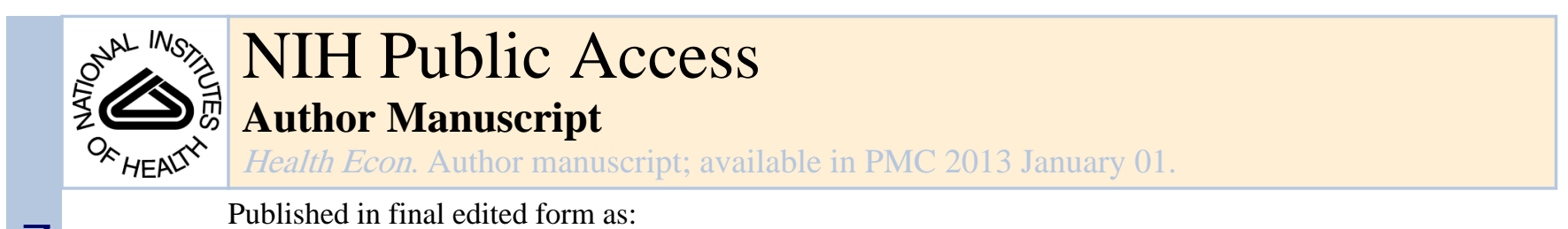

Published in final edited form as:

Health Econ. 2012 January ; 21(1): 24-29. doi:10.1002/hec.1802.

\title{
The Developmental Origins of Health 1
}

\author{
James J. Heckman \\ University of Chicago, University College Dublin, American Bar Foundation
}

\begin{abstract}
This paper argues that health economists should consider the costs and benefits of preventing rather than treating disease. It sketches a developmental approach to health that examines the costs and benefits of interventions over the life cycle.
\end{abstract}

\section{Keywords}

Health; Prevention; Remediation; Capabilities; Technology of Capability Formation

I congratulate the editors of Health Economics for twenty successful years. Continued success requires publishing research at the frontiers of knowledge. One frontier is the developmental origins of health.

Among early deaths in the United States, some claim that $40 \%$ are due to patterns of behavior, $30 \%$ are due to genetic predispositions, $15 \%$ are due to social circumstances, and $10-15 \%$ are due to shortfalls in medical care (McGinnis et al., 2002). It is a matter of record that the U.S. spends trillions of dollars on health, $95 \%$ of which is on treatment, not prevention. Much contemporary research in health economics studies the costs and benefits of alternative treatment and delivery systems. In contrast, research has only started to consider how early life prevention and later life remediation can extend the quality and length of life and avoid costly treatment ${ }^{1}$.

Two distinct bodies of research suggest that the early years of childhood shape many adult behaviors and outcomes. The "fetal programming" literature surveyed in Gluckman and Hanson (2006) demonstrates that in utero environments affect adult health. The essays in Gluckman and Hanson discuss the importance of a variety of early environments on adult health. Fogel $(1997,2004)$ shows that early nutrition affects adult health. Barker (1998) demonstrates that environmental insults in utero and in infancy predict the onset of adult coronary disease, stroke, diabetes and hypertension. Fetal and maternal nutrition are important predictors of adult health. Currie $(2009,2011)$ and Almond and Currie (2011) survey empirical relationships between early-life conditions and adult health reported in the recent literature in economics.

\footnotetext{
${ }_{1}^{1}$ thank Gabriella Conti and Tim Kautz for very helpful comments. This research was supported by NIH R01-HD32058, NIH R01HD054702, NIH R01-HD065072, The J.B. and M.K. Pritzker Foundation, a grant from the Institute for New Economic Thinking to The Milton Friedman Institute, European Research Council Grant no. 269874 to University College Dublin, The California Endowment, The Commonwealth Fund, The Nemours Foundation, an anonymous funder, and The American Bar Foundation. James Heckman, The University of Chicago, Department of Economics, 1126 E. $59^{\text {th }}$ St., Chicago, IL 60637, (773) 702-0634, jjh@uchicago.edu.

JEL codes: I12, I18

${ }^{1}$ By prevention, I mean primary prevention that prevents the emergence of disease.
} 
While epidemiologists typically adopt a life cycle, developmental, perspective (see, e.g., Davey-Smith, 2007), most health economists do not. For example, the influential analysis of Grossman $(1972,2000)$ focuses exclusively on adult health investment decisions, taking the childhood health endowment and adult preferences as given. Galama and van Kippersluis (2010) and Galama (2011) substantially extend the Grossman framework. However, they do not model how preferences or childhood endowments are determined.

Parallel to the epidemiological literature, an emerging developmental literature in economics demonstrates the importance of early environmental conditions on the evolution of adolescent and adult cognitive and noncognitive capabilities (see, e.g., Knudsen et al., 2006; Cunha and Heckman, 2007). These capabilities strongly influence educational attainment, criminal behavior, earnings, and participation in risky behaviors (see Almlund et al., 2011). Like the fetal programming literature, this literature documents critical and sensitive periods in the development of capabilities. Unlike the fetal programming literature, it also considers environmental influences on development over the entire life cycle from childhood through adulthood.

Remediation of early disadvantage and resilience in response to adversity receive much more attention in this literature than in the current literature in health economics. For policy purposes, it is not enough to know that early-life conditions matter. It is important to know the costs and benefits of remediating early life deficits.

Each literature has much to learn from the other. Evidence on the importance of early environments on a spectrum of health, labor market, and behavioral outcomes, suggests that common developmental processes are at work.

Cognitive and noncognitive capabilities - self-regulation, motivation, time preference, farsightedness, adventurousness and the like - affect the evolution of health capital by influencing choices made by parents and children including educational choices. In turn, education shapes personality and cognitive traits (Almlund et al., 2011; Heckman et al., 2006, 2011). Grossman (2000), Cutler and Lleras-Muney (2010), Conti et al. (2010a,b), and Heckman et al. (2011) show that education also causally affects health. Personality and cognition determine health and healthy behaviors beyond their direct e ects on education and through the e ects of education on health (Conti et al., 2010a,b, 2011).

Those with greater self-control and conscientiousness better follow medical instructions and take care of themselves. Certain personality types are at greater risk for health and mental health disorders (Borghans et al., 2008; Deary et al., 2010; Almlund et al., 2011). Personality traits affect learning (Duncan et al., 2007; Raver et al., 2007; Cunha and Heckman, 2008). Adverse health conditions impair learning (Currie, 2009). Ram and Schultz (1979) show that raising life expectation promotes investment in human capital. People with longer horizons and lower rates of time preference invest more in themselves. Lower rates of time preference are associated with greater cognitive skills ${ }^{2}$.

The recent literature on personality and preference formation establishes causal impacts of parental inputs, social environments, schools, and other environmental factors in producing cognitive and noncognitive capabilities (Cunha and Heckman, 2007, 2009; Cunha et al., 2010). The parameters of the Grossman model and the models of Galama and van Kippersluis (2010) and Galama (2011) are the outputs of a developmental model.

\footnotetext{
${ }^{2}$ See the evidence reviewed in Almlund et al. (2011)
} 
A developmental focus suggests new channels of policy influence to remediate welldocumented health disparities. Early childhood interventions that affect the personality and cognitive traits that promote health can be e ective policy tools to prevent and cure disease.

A simple investment framework unifies the literature on health and capability formation. It also reveals currently unexplored avenues for future research. The framework can be used to analyze synergies in producing health, cognitive and noncognitive capabilities. An econometric approach based on dynamic latent variables operationalizes this framework (see Cunha and Heckman, 2008, Cunha et al., 2010). This approach recognizes the proxy nature of variables like birthweight, height, nutrition, IQ scores, and measures of personality and mental illness that play prominent roles in empirical work in epidemiology, education and health economics.

\section{The Economics of Human Development}

Capabilities, incentives, and motivations jointly shape behavior. Capabilities emerge early. They are not set in stone and can be fostered. Families and environments play a powerful role in shaping these traits. A neglected avenue of investigation to promote health is interventions that form these capabilities by exploiting the synergisms among diverse policies. A good health policy may be a good family policy. This argument goes beyond considering education (e.g., Becker, 1964) or nutrition (Barker, 1998) but is consistent with both and integrates these more specialized emphases into a general framework.

Recent studies in the economics of human development establish that: (1) A core lowdimensional set of capabilities explains a variety of diverse socioeconomic outcomes; (2) Cognitive and noncognitive capabilities equally affect many outcomes; (3) Early health conditions also play a powerful role in explaining adult behaviors.

Early gaps in cognitive ability persist strongly, especially after the primary grades. Gaps in noncognitive capabilities persist less strongly. The fluidity of personality traits over the adolescent years is associated with the slowly emerging prefrontal cortex (see the evidence cited in Heckman, 2008 and Steinberg, 2008). Many early childhood interventions operate primarily through their e ects on noncognitive capabilities. At current levels of practice, adolescent remediation for cognitive deficits is ine ective. Adolescent interventions in personality are far more e ective (see Cunha et al., 2006; Cunha and Heckman, 2009; Almlund et al., 2011).

\section{A Framework For Analyzing The Expression and Evolution of Capabilities}

Cunha and Heckman $(2007,2009)$ and Heckman (2007) develop a framework for analyzing the expression and evolution of capabilities. Define a capability vector ${ }_{t}$ at age $t$ :

$$
\theta_{t}=(\underbrace{\theta_{C, t}}_{\text {Cognitive }}, \underbrace{\theta_{N, t}}_{\text {Noncognitive }}, \underbrace{\theta_{H, t}}_{\text {Health }}) .
$$

Each component may be a vector. Outcome $j$ at time $t, Y_{j, t}$ depends on capabilities ${ }_{t}$ and effort $e_{j, t}$ devoted to the outcome as well as social context (background) variables $t, B$ :

$$
Y_{j, t}=\phi_{j, t}\left(\theta_{t,}, e_{j, t}, \theta_{t, B}\right) \quad j=1, \ldots, J \quad t=1, \ldots, T .
$$

Effort devoted to activity $j$ at time $t, e_{j, t}$, depends on rewards and endowments: 


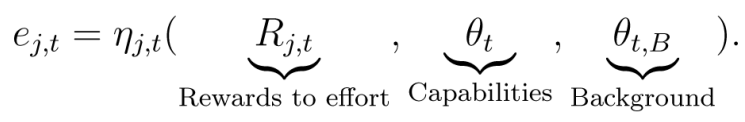

Cognition, personality and health stocks determine health outcomes and healthy behaviors.

The technology of capability formation (Cunha and Heckman, 2007; Heckman, 2007) represents the dynamics of capability formation as an equation of motion:

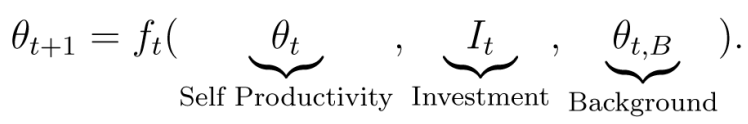

It has been applied to analyze a variety of data sets on a variety of outcomes includng wages, crime, health and healthy behaviors, using a common core of capabilities. ${ }^{3}$. Estimates reveal sensitive periods in early life (before age 10) for cognitive capabilities and sensitive periods for noncognitive capabilities through adolescence (Cunha et al., 2010) ${ }^{4}$.

There is substantial evidence of synergies among productive traits, $\frac{\partial \theta_{t+1}}{\partial \theta_{t}} \geq 0$, as well as for dynamic complementarity, $\frac{\partial^{2} \theta_{t+1}}{\partial \theta_{t} \partial I_{t}^{\prime}} \geq 0$, and for productivity of investment, $\frac{\partial \theta_{t+1}}{\partial I_{t}} \geq 0$.

Figure 1 summarizes the framework graphically. Some progress has been made in estimating the linkages displayed in this figure but most remain unknown. The figure suggests both opportunities and dangers. Investments and environments shape capabilities. There are many possible stages and strategies for intervention. Understanding at what stages investments are most e ective for shaping which capabilities will inform policy. To make wise policy choices, it is necessary to have a deep understanding of the mechanisms displayed in Figure 1.

Knowing that early-life conditions causally affect adult health does not tell us the channels through which early-life conditions operate or the mechanisms through which e ective remediation might operate. Early-life conditions might trigger a series of later-life events that shape the capabilities that produce adult outcomes. Perhaps later-life interventions can be highly e ective. Alternatively, early-life conditions might affect biology in an irreversible way. In that case, early life interventions are essential. The current literature o ers only hints at answers to these questions. When the causal links of Figure 1 are fleshed out, health economists will be better able to suggest wise policies for promoting the capabilities that produce health.

\section{Does Education Promote Health?}

Consider an example of research on one channel of influence displayed in Figure 1. Is education policy a promising avenue for promoting health? Specifically what is the e ect of education in the adolescent years (an investment) on health and healthy behaviors? What is the relative importance of adolescent education compared to factors formed before the adolescent years?

\footnotetext{
${ }^{3}$ See the review in Almlund et al. (2011)

${ }^{4}$ Sensitive periods are periods where investment is more productive than other periods. Critical periods are the only periods where investment is productive. See Cunha and Heckman (2009) for precise definitions of these concepts
} 
The developmental approach recognizes that schooling promotes cognition and personality. Schooling promotes health and healthy behaviors (Cutler and Lleras-Muney, 2010; Lochner, 2011; Conti et al., 2011; Currie and Moretti, 2003). There is a feedback loop as suggested in Figure 1. Enhanced capabilities promote schooling. Cognitive and noncognitive traits promote health and healthy behaviors.

Figure 2, based on British data analyzed by Conti et al. (2010a,b), shows the e ect (by gender) of attendance beyond compulsory schooling on health and healthy behaviors measured at age 30 . There is a strong causal e ect of compulsory education on health and healthy behaviors. Factors formed before adolescence also matter but to different extents for different outcomes. E ects of education are heterogenous across individuals, not only in magnitude but also in terms of sign. Recent research estimates the distribution of health responses to education (see Conti and Heckman, 2010). An important finding of this literature is that failure to control for personality traits overstates the relative importance of cognitive traits in predicting adult health (Conti et al., 2010a,b, 2011).

\section{Summary}

The developmental approach to the study of health promises to produce a deeper understanding of both prevention and remediation strategies. Understanding the dynamic mechanisms of causation is essential for devising wise policies. It is not enough to know that early-life conditions help shape later-life outcomes. We need to trace the e ects of early-life outcomes on intermediate-life investments and environments in order to understand when and for what intervention can be e ective.

\section{References}

Almlund, M.; Duckworth, A.; Heckman, JJ.; Kautz, T. Personality psychology and economics. In: Hanushek, EA.; Machin, S.; Wößmann, L., editors. Handbook of the Economics of Education. Vol. 4. Elsevier; Amsterdam: 2011. Forthcoming

Almond, D.; Currie, J. Human capital development before age five. In: Ashen-felter, O.; Card, D., editors. Handbook of Labor Economics. Vol. 4B. Elsevier; North Holland: 2011. p. 1315-1486.Chapter 15

Barker, DJP. Mothers, Babies and Health in Later Life. 2nd ed.. Churchill Livingstone; Edinburgh: 1998.

Becker, GS. Human Capital: A Theoretical and Empirical Analysis, With Special Reference to Education. National Bureau of Economic Research; New York: 1964.

Borghans L, Duckworth AL, Heckman JJ, ter Weel B. The economics and psychology of personality traits. Journal of Human Resources. 2008 Fall;43(4):972-1059.

Conti G, Heckman JJ. Understanding the Early Origins of the Education-Health Gradient: A Framework that can also be Applied to Analyze Gene-Environment Interactions. Forthcoming, Perspectives on Psychological Science. 2010

Conti G, Heckman JJ, Lopes HF, Piatek R. Constructing economically justified aggregates: An application to the early origins of health. Under revision, Journal of Econometrics. 2011

Conti, G.; Heckman, JJ.; Urzua, S. Early endowments, education, and health. University of Chicago, Department of Economics; 2010a. Unpublished manuscript

Conti G, Heckman JJ, Urzua S. The education-health gradient. American Economic Review: Papers and Proceedings. May; 2010b 100(2):1-5.

Cunha F, Heckman JJ. The technology of skill formation. American Economic Review. May; 2007 97(2):31-47.

Cunha F, Heckman JJ. Formulating, identifying and estimating the technology of cognitive and noncognitive skill formation. Journal of Human Resources. 2008; 43(4):738-782. Fall.

Cunha F, Heckman JJ. The economics and psychology of inequality and human development. Journal of the European Economic Association. Apr; 2009 7(2-3):320-364. [PubMed: 20209045] 
Presented as the Marshall Lecture; European Economics Association, Milan, Italy. August 29, 2008;

Cunha, F.; Heckman, JJ.; Lochner, LJ.; Masterov, DV. Interpreting the evidence on life cycle skill formation. In: Hanushek, EA.; Welch, F., editors. Handbook of the Economics of Education. North-Holland; Amsterdam: 2006. p. 697-812.Chapter 12

Cunha F, Heckman JJ, Schennach SM. Estimating the technology of cognitive and noncognitive skill formation. Econometrica. May; 2010 78(3):883-931. [PubMed: 20563300]

Currie J. Healthy, wealthy, and wise: Socioeconomic status, poor health in childhood, and human capital development. Journal of Economic Literature. 2009; 47(1):87-122.

Currie J. Inequality at birth: Some causes and consequences. American Economic Review. 2011; 101(3):1-22.

Currie J, Moretti E. Mother's education and the intergenerational transmission of human capital: Evidence from college openings. Quarterly Journal of Economics. 2003; 118(4):1495-1532.

Cutler DM, Lleras-Muney A. Understanding di erences in health behaviors by education. Journal of Health Economics. Jan; 2010 29(1):1-28. [PubMed: 19963292]

Davey-Smith G. Life-course approaches to inequalities in adult chronic disease risk. Proceedings of the Nutrition Society. 2007; 66(02):216-236. [PubMed: 17466104]

Deary IJ, Weiss A, Batty GD. Intelligence and personality as predictors of illness and death: How researchers in di erential psychology and chronic disease epidemiology are collaborating tounderstand and address health inequalities. Psychological Science in the Public Interest. 2010; 11(2):53-79.

Duncan GJ, Dowsett CJ, Claessens A, Magnuson K, Huston AC, Klebanov P, Pagani L, Feinstein L, Engel M, Brooks-Gunn J, Sexton H, Duckworth K, Japel C. School readiness and later achievement. Developmental Psychology. 2007; 43(6):1428-1446. [PubMed: 18020822]

Fogel, RW. New findings on secular trends in nutrition and mortality: Some implications for population theory. In: Rosenzweig, MR.; Stark, O., editors. Handbook of Population and Family Economics. Vol. 1A. Elsevier Science; Amsterdam: 1997. p. 433-481.

Fogel, RW. The Escape from Hunger and Premature Death, 1700-2100: Europe, America and the Third World. Cambridge University Press; Cambridge: 2004.

Galama T. A contribution to health capital theory. 2011 RAND Working Paper WR-831, RAND Corporation.

Galama T, van H. A theory of socioeconomic disparities in health over the life cycle. 2010 RAND Corporation Working Paper No. WR773.

Gluckman, PD.; Hanson, MA. Developmental Origins of Health and Disease. Cambridge University Press; Cambridge, UK: 2006.

Grossman M. On the concept of health capital and the demand for health. Journal of Political Economy. Mar-Apr;1972 80(2):223-255.

Grossman, M. The human capital model. In: Culyer, AJ.; Newhouse, JP., editors. Handbook of Health Economics. Vol. 1. Elsevier; Amsterdam: 2000. p. 347-408.

Heckman JJ. The economics, technology and neuroscience of human capability formation. Proceedings of the National Academy of Sciences. Aug; 2007 104(3):13250-13255.

Heckman JJ. Schools, skills and synapses. Economic Inquiry. Jul; 2008 46(3):289-324. [PubMed: 20119503]

Heckman, JJ.; Humphries, JE.; Urzúa, S.; Veramendi, G. The e ects of educational choices on labor market, health, and social outcomes. Unpublished manuscript, University of Chicago, Department of Economics; 2011.

Heckman JJ, Stixrud J, Urzua S. The e ects of cognitive and noncognitive abilities on labor market outcomes and social behavior. Journal of Labor Economics. Jul; 2006 24(3):411-482.

Knudsen EI, Heckman JJ, Cameron J, Shonko JP. Economic, neurobiological, and behavioral perspectives on building America's future workforce. Proceedings of the National Academy of Sciences. Jul; 2006 103(27):10155-10162.

Lochner, L. Non-production benefits of education: Crime, health, and good citizenship. National Bureau of Economic Research; 2011. Working Paper 16722 
McGinnis JM, Williams-Russo P, Knickman JR. The case for more active policy attention to health promotion. Health A airs. Mar-Apr;2002 21(2):78-93.

Ram R, Schultz TW. Life span, health, savings, and productivity. Economic Development and Cultural Change. Apr; 1979 27(3):399-421.

Raver, CC.; Garner, PW.; Smith-Donald, R. The roles of emotion regulation and emotion knowledge for children's academic readiness: Are the links causal?. In: Pianta, RC.; Cox, MJ.; Snow, KL., editors. School Readiness and the Transition to Kindergarten in the Era of Accountability. Brookes Publishing; Baltimore, MD: 2007.

Steinberg L. A social neuroscience perspective on adolescent risk-taking. Developmental Review. 2008; 28(1):78-106. [PubMed: 18509515] 


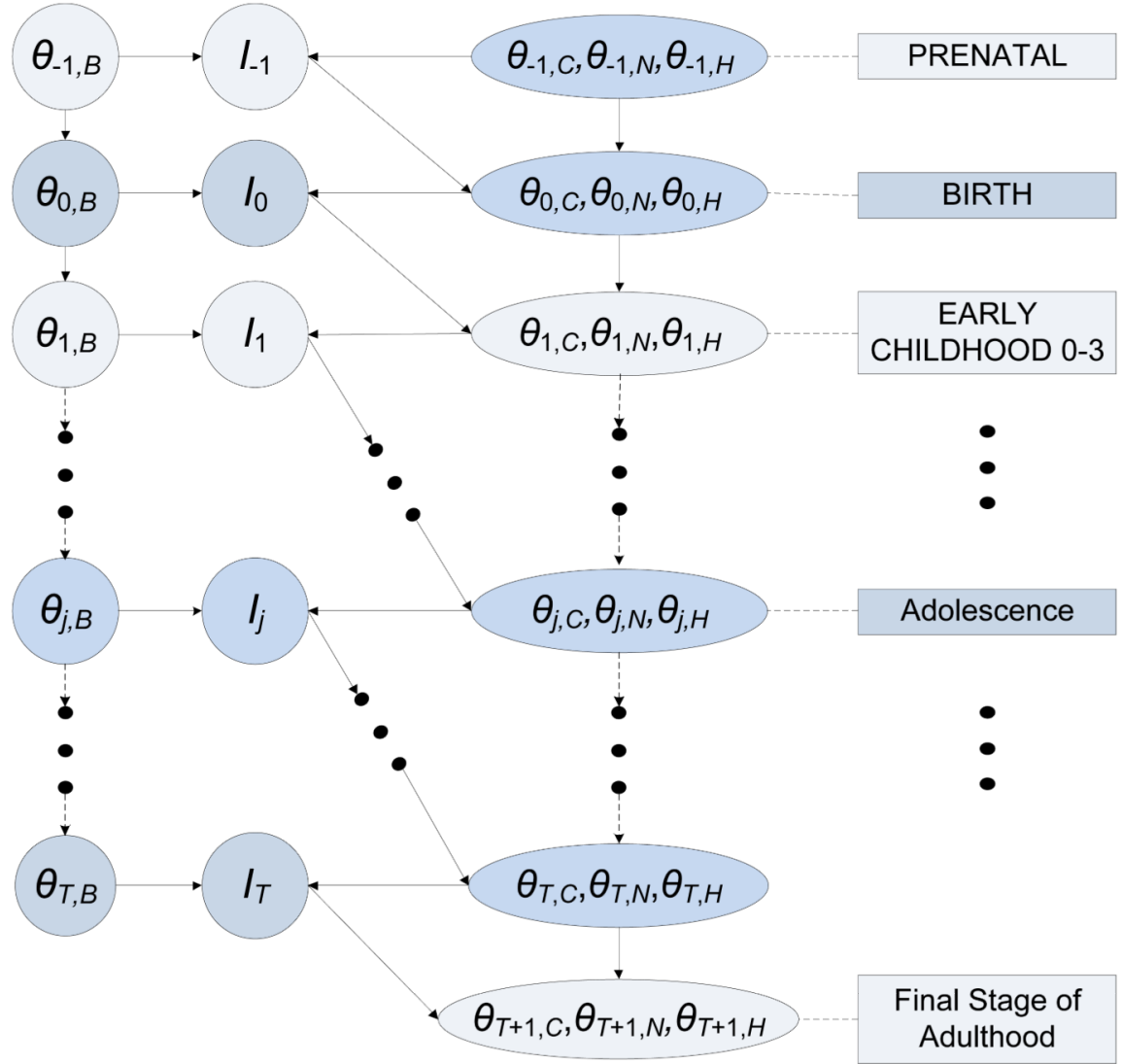

Figure 1.

A Life Cycle Framework for The Development of Capabilities $\theta_{t}=\left(\theta_{C, t}, \theta_{N, t}, \theta_{H, t}\right)$ capacities at $t$ $I_{t}$ investment at $t$ $\theta_{t, B}$ background factors (context) $\theta_{t+1}=f_{t}\left(\theta_{t}, I_{t}, \theta_{t, B}\right)$ 


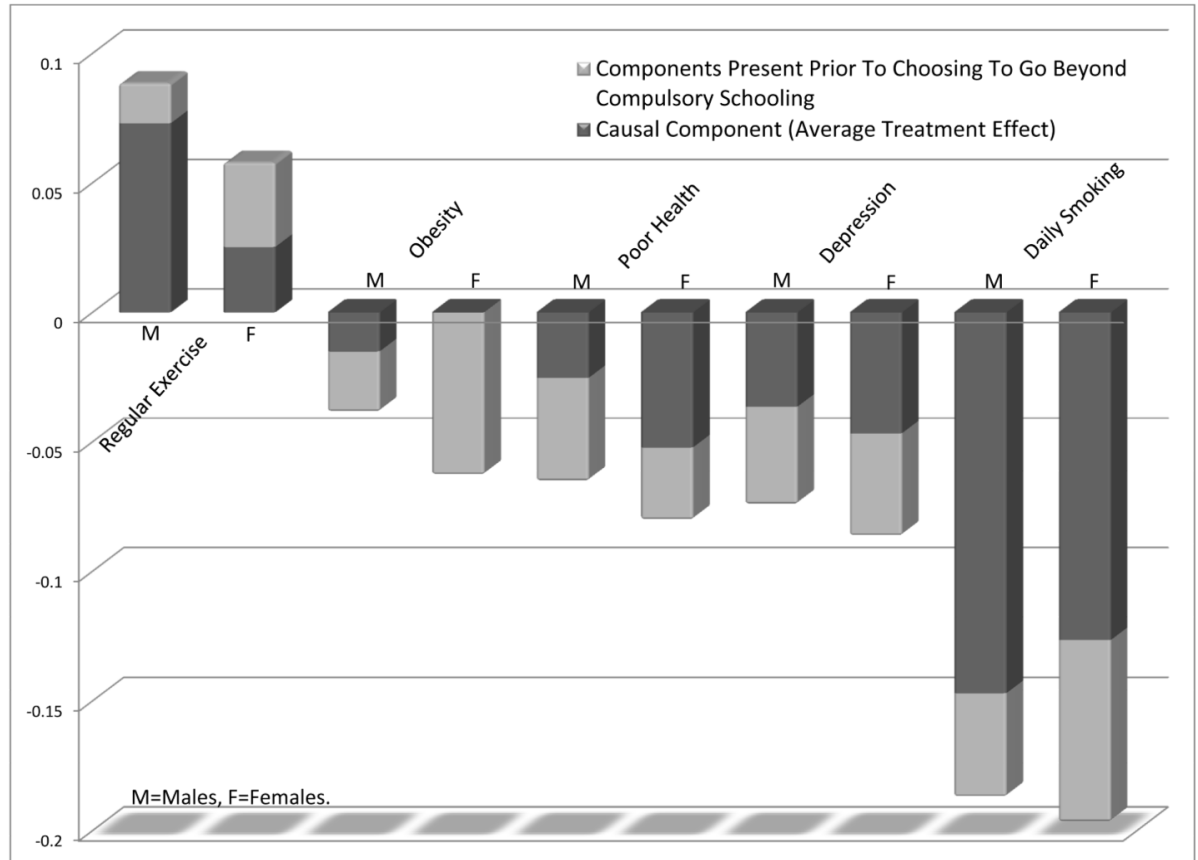

Figure 2.

The Causal E ect of Education Beyond Compulsory Schooling on Health and Healthy Behaviors

Source: Conti et al. (2010a,b), British Cohort Study 1970 